\title{
Epigenetic Alterations of the Promoter Region of the POMC Gene in Adolescent Depressive Disorder Patients with Nonsuicidal Self-Injury Behaviors [Erratum]
}

Zheng D, Bi X, Zhang T, et al. Psychol Res Behav Manag. 2020;13:997-1008.

The authors have advised that there are several errors in the published paper which were introduced by the Editorial staff during the publication process.

A

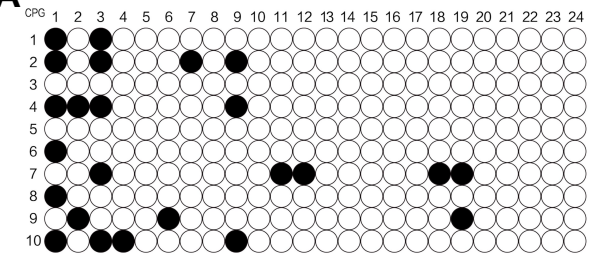

C

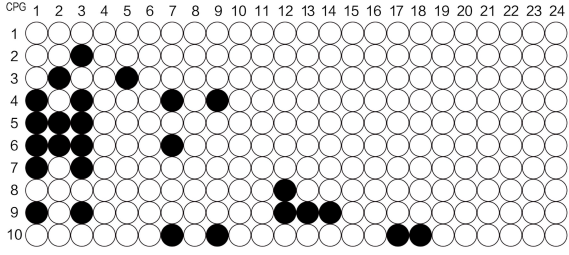

E



G

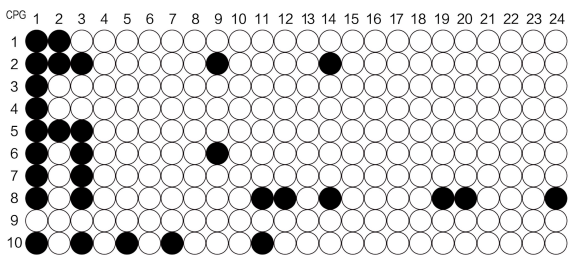

I

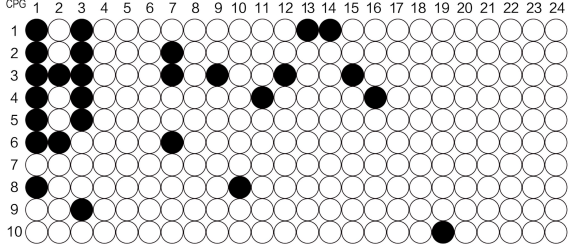

Pages 1001-1003, Figure 1 parts N, R, X, Y, Z, CC and $\mathrm{DD}$ are incorrect. The correct figure is shown below.

B

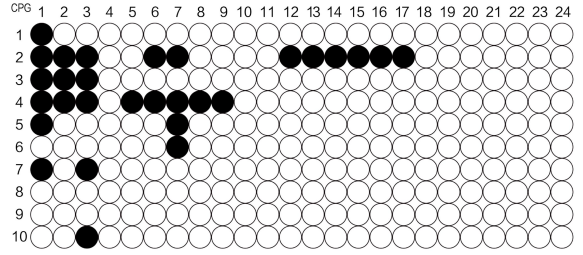

D

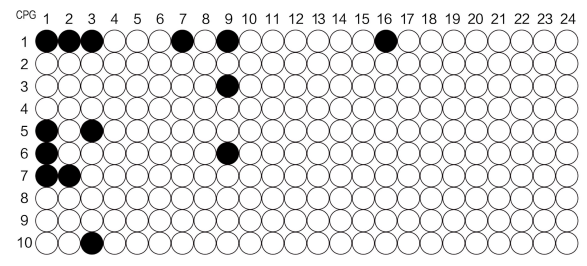

$\mathbf{F}$

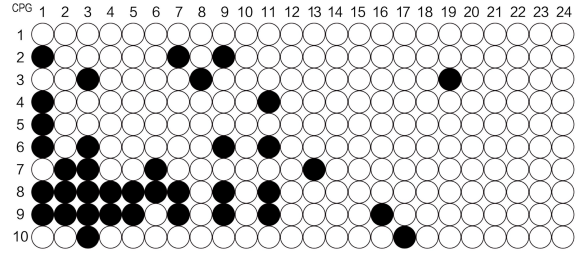

H

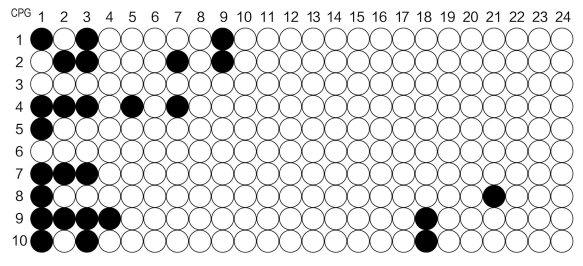

$\mathbf{J}$

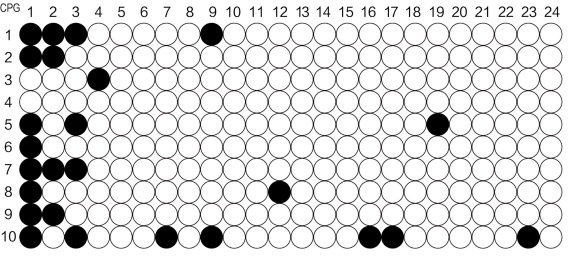

Figure I (Continued).

DovePress

Psychology Research and Behavior Management 2021:14 27-30 
K

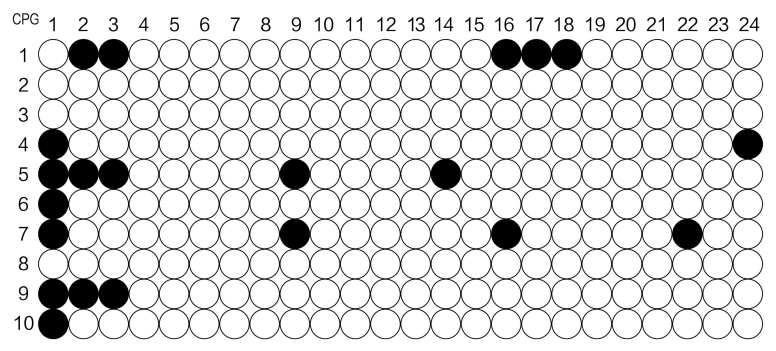

M

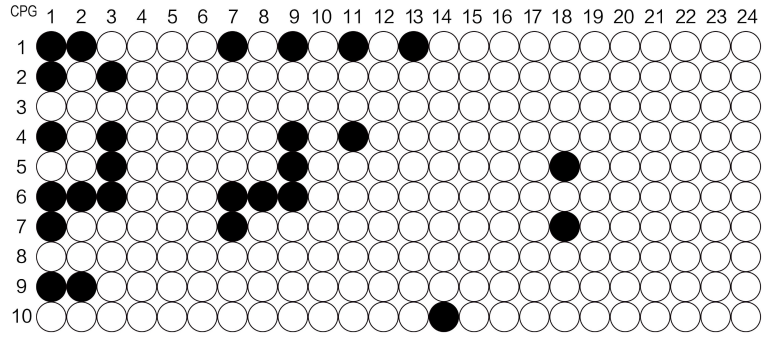

O

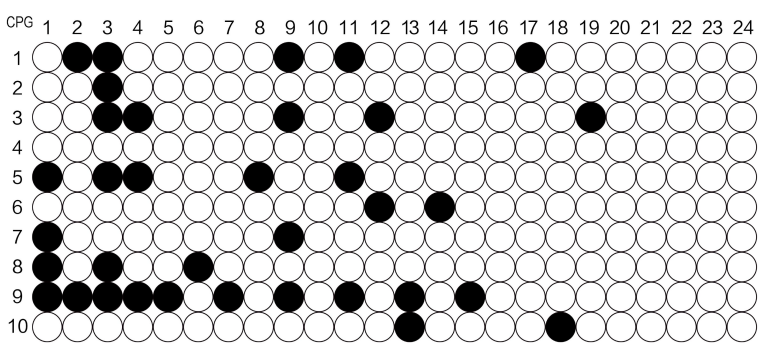

Q

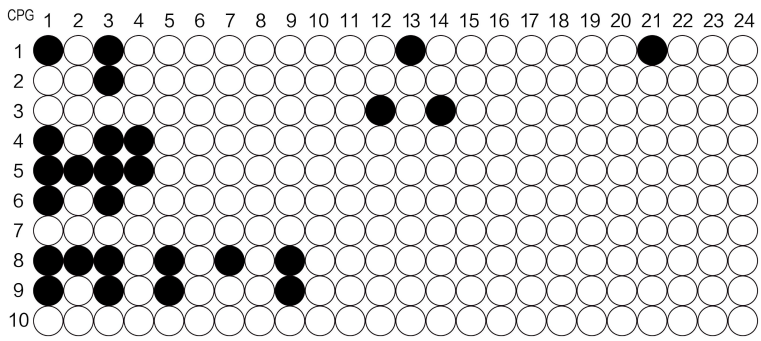

$\mathbf{S}$

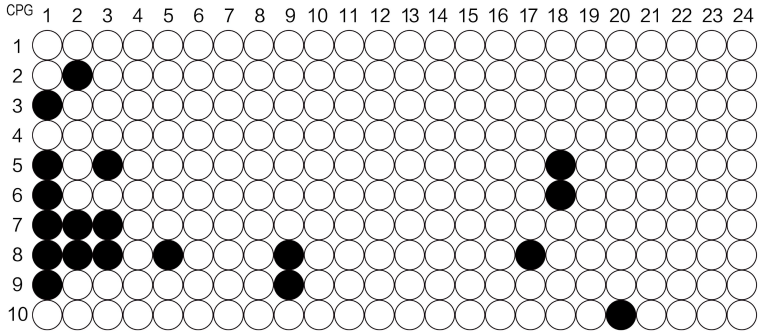

$\mathbf{L}$

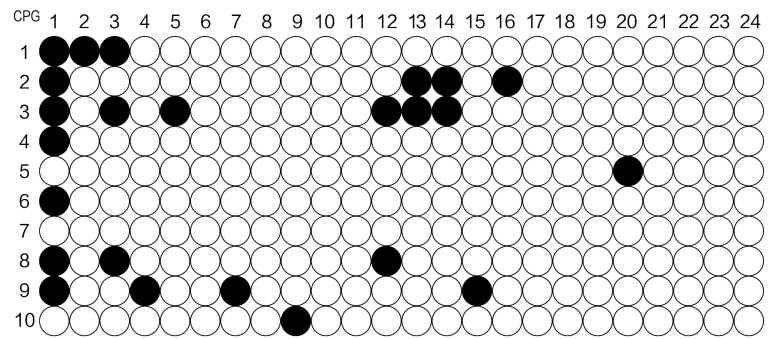

$\mathbf{N}$

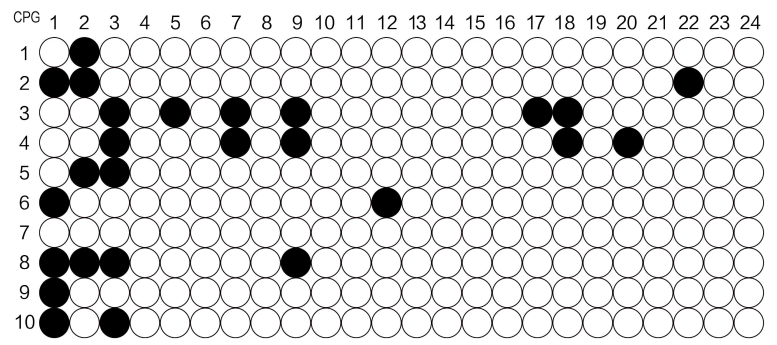

$\mathbf{P}$

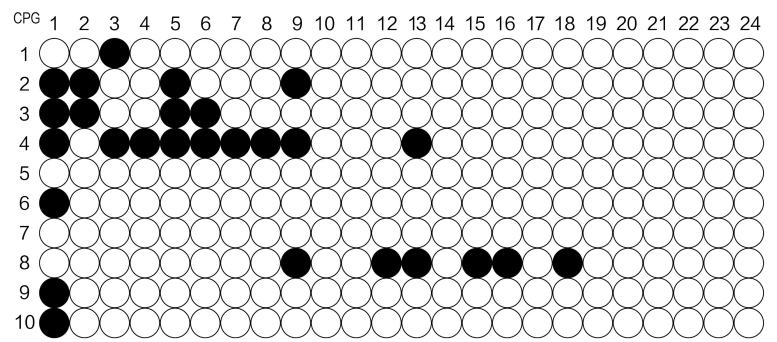

$\mathbf{R}$

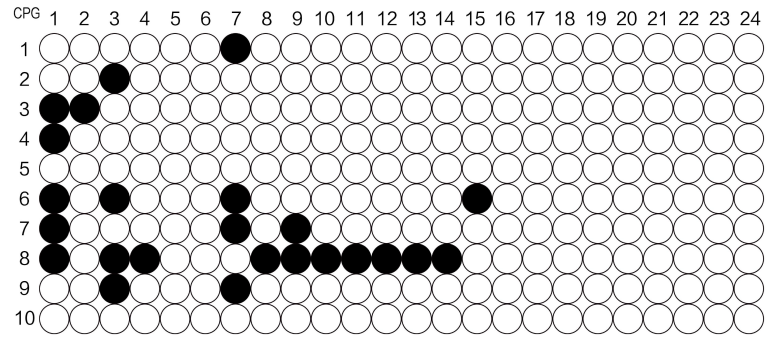

$\mathbf{T}$



Figure I (Continued) 
$\mathbf{U}$

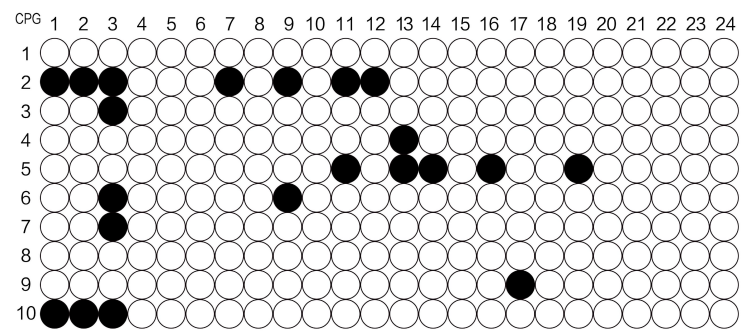

W

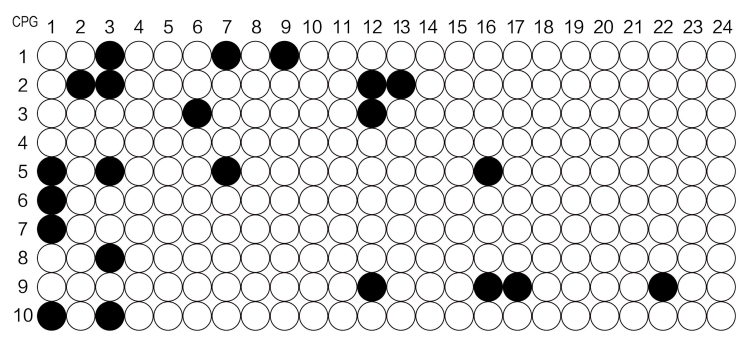

$\mathbf{Y}$

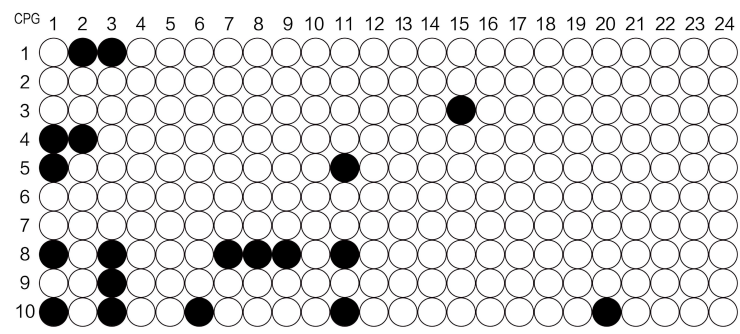

AA

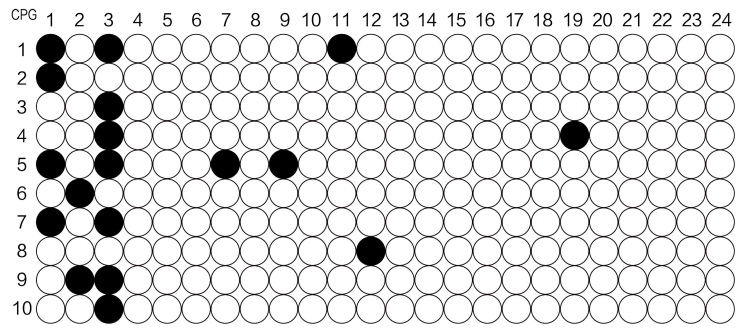

CC

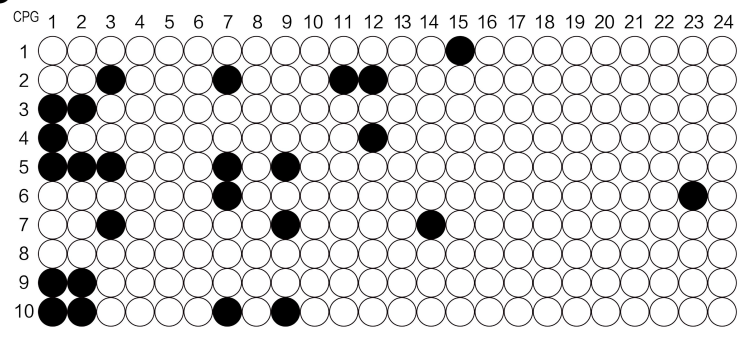

V

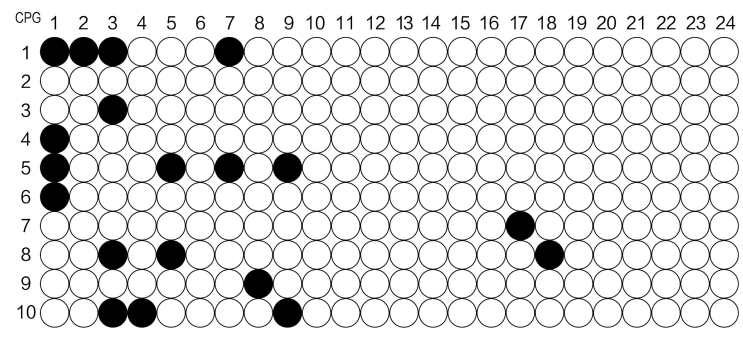

$\mathbf{X}$

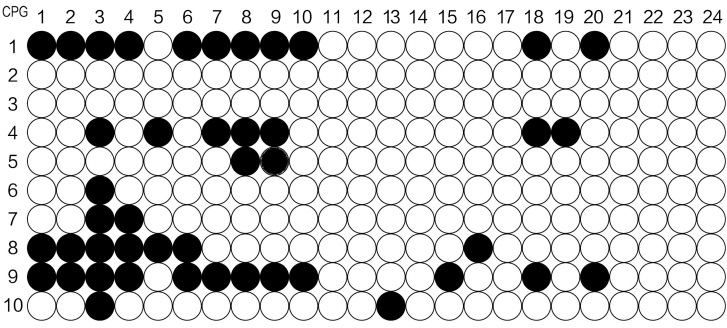

$\mathbf{Z}$

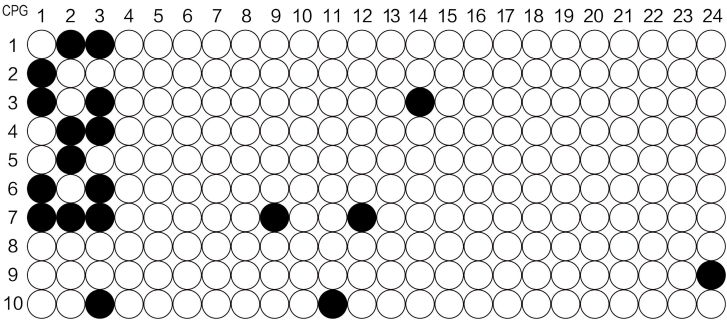

BB

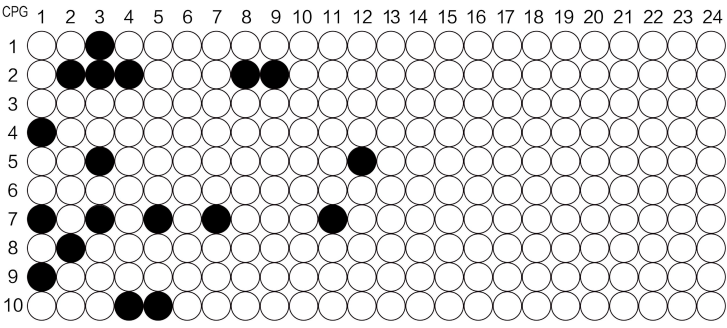

DD

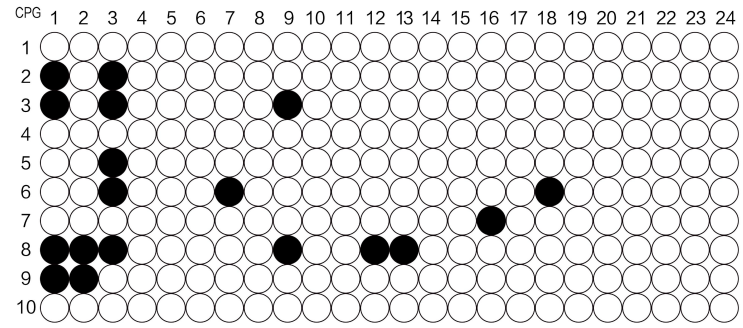

Figure I The level of methylation of the POMC gene in different sites.

Notes: (A-O) represented the level of methylation of 15 adolescent depressive disorder patients with NSSI behaviors; (P-DD) represented the level of methylation of 15 HCs. 
Page 1006, Table 2, part $\mathrm{F}$, the formatting of the table is incorrect. The correct formatting is shown below.

\begin{tabular}{|c|c|c|c|c|c|}
\hline \multicolumn{6}{|l|}{ (F) } \\
\hline Gender & Group & CpG2I & CpG22 & CpG23 & CpG24 \\
\hline \multirow[t]{2}{*}{ Male } & Case group & $0.20 \pm 0.45$ & $0.20 \pm 0.45$ & $0.20 \pm 0.45$ & $0.20 \pm 0.45$ \\
\hline & Control group & $0.00 \pm 0.00$ & $0.17 \pm 0.41$ & $0.00 \pm 0.00$ & $0.17 \pm 0.41$ \\
\hline$t$ & & 1.000 & 0.129 & 1.000 & 0.129 \\
\hline$P$ & & 0.374 & 0.900 & 0.374 & 0.900 \\
\hline \multirow[t]{2}{*}{ Female } & Case group & $0.00 \pm 0.00$ & $0.10 \pm 0.32$ & $0.00 \pm 0.00$ & $0.10 \pm 0.32$ \\
\hline & Control group & $0.11 \pm 0.33$ & $0.00 \pm 0.00$ & $0.22 \pm 0.44$ & $0.00 \pm 0.00$ \\
\hline$t$ & & -1.058 & 1.000 & -1.512 & 1.000 \\
\hline$P$ & & 0.305 & 0.343 & 0.169 & 0.343 \\
\hline
\end{tabular}

\section{Publish your work in this journal}

Psychology Research and Behavior Management is an international, peer-reviewed, open access journal focusing on the science of psychology and its application in behavior management to develop improved outcomes in the clinical, educational, sports and business arenas. Specific topics covered in the journal include: Neuroscience, memory and decision making; Behavior modification and management; Clinical applications; Business and sports performance management; Social and developmental studies; Animal studies. The manuscript management system is completely online and includes a very quick and fair peer-review system, which is all easy to use. Visit http://www. dovepress.com/testimonials.php to read real quotes from published authors. 